\title{
'Items for criticism (not in sequence)': Joseph DeLee, Pare Lorentz and The Fight for Life (1940)
}

\author{
CAITJAN GAINTY*
}

\begin{abstract}
In the late 1920s, the American obstetrician Joseph DeLee brought the motionpicture camera into the birth room. Following that era's trend of adapting industrial efficiency practices for medical environments, DeLee's films give spectacular and unexpected expression to the engineering concept of 'streamlining'. Accomplishing what more tangible obstetric streamlining practices had failed to, DeLee's cameras, and his post-production manipulation, shifted birth from messy and dangerous to rationalized, efficient, death-defying. This was film as an active and effective medical tool. Years later, the documentarian Pare Lorentz produced and wrote his own birth film, The Fight for Life (1940). The documentary subject of the film was DeLee himself, and the film was set in his hospitals, on the same maternity 'sets' that had once showcased film's remarkable streamlining capacity to give and keep life. Yet relatively little of DeLee was retained in the film's content, resulting in a showdown that, by way of contrast, further articulated DeLee's understanding of film's medical powers and, in so doing, hinted at a more dynamic moment in the history of medicine while speaking also to the process by which that understanding ceased to be historically legible.
\end{abstract}

In 1940, The Fight for Life hit American cinemas. Written and directed by Pare Lorentz, the film was loosely based on a book of the same name by the celebrated biologistturned-author Paul de Kruif, whose columns on science and medicine often appeared in the Ladies Home Journal and other popular magazines, and whose books (most famously Microbe Hunters) detailed the heroic exploits of modern-day medical science. His work The Fight for Life had continued in this vein, standing as a paean in prose to American physicians who were, as de Kruif put it, 'fighters for life'. ${ }^{1}$ The hero of the chapter was the obstetrician Joseph B. DeLee.

* Centre for the History of Science, Technology and Medicine, Department of History, King's College London, Strand, London, WC2R 2LS, UK. Email: caitjan.gainty@kcl.ac.uk.

I am indebted to Sue Sacharski at the Northwestern Memorial Hospital Archives for her generous archival assistance. I am also grateful to Agnes Arnold-Forster for collecting further material on Pare Lorentz, and to Gail Isenberg for critical information about the DeLee film collection under her stewardship at the University of Chicago. I thank especially Tom Gunning, Jesse Olszynko-Gryn, Kathryn Schoefert, Tim Boon and Oliver Gaycken for their insights. And finally I thank Lucas Canino for his thoughtful comments and editorial guidance over many many drafts.

1 Paul de Kruif, The Fight for Life, New York: Harcourt Brace, 1938 (previously published 1934, 1935, 1936, 1937). The Fight for Life (1940), directed and produced by Lorentz under the auspices of the shortlived United States Film Service, is viewable online via the International Documentary Association at www. documentary.org/films-pare-lorentz/fight-life. On the Film Service see Richard Couch and Thomas Hunt, 'The rise and fall of the United States Film Service', International Journal of Instructional Media (1994) 21, pp. 239-253. 
As Lorentz later recalled in his autobiography FDR's Filmmaker - where he credits himself with, among other things, having given his friend John Steinbeck the title for The Grapes of Wrath - de Kruif had been moved to entrust the director with the dramatic rights to all of his books via telegram after watching the pair of earlier films he had written and directed, on the work of the New Deal. ${ }^{2}$ The success of the first of these, the 1936 Dust Bowl feature The Plow that Broke the Plains, had led to the second in 1938, The River (for which he garnered a Pulitzer Prize nomination when it appeared in book form). The Fight for Life would be his final film for Roosevelt's New Deal administration. In writing the screenplay, Lorentz focused only on the first section of de Kruif's book, DeLee's story.

This final film of his social trilogy marked a new style for Lorentz, whose previous films had not involved actors and instead had relied on a powerful 'symphony', as Lorentz himself described it, of evocative musical score, visually stunning images and Walt Whitman-like narration to tell their stories about environmental degradation. ${ }^{3}$ The Fight for Life, however, took DeLee's obstetric work and fictionalized it. Lorentz hired professional actors to play the major characters, but cast many of the doctor's own Maternity Center staff and patients (credited as 'women of the city') to populate the scenes. Most filming took place on location in DeLee's Lying-In Hospital, in the homes of patients, and in DeLee's locally beloved Chicago Maternity Center, located in one of Chicago's roughest neighbourhoods - the 'Bloody Twentieth'. This was smoothly spliced with footage shot around Chicago and other Midwestern cities and, for the final scene, in Hollywood.

The film opens on an obstetrical team delivering a baby in an exaggerated and highly choreographed version of modern childbirth, in which each aspect of the event was tightly controlled. The place is called the 'Chicago Memorial Hospital', but it is actually shot on location in DeLee's own 'Lying-In Hospital', described in de Kruif's book as one half of DeLee's two-tiered approach to childbirth (DeLee's hospital served the wealthy, his Maternity Center the poor).

As the metronomic score beats a steady march, the doctors and nurses whirl around and above an expectant mother, whose body lies shrouded beneath an enormous white sheet. Her sudden, strange facial contortion is the only signal that birth is imminent, and as she is masked with an apparatus administering a drug cocktail, the music shifts to mark the heartbeat of the arriving baby. The medical team pause, each framed in turn by the camera, as the music swells to the dramatic moment when the baby appears and is lifted from beneath the sheet into a bassinet. But as the delivery room relaxes into calm, it slowly becomes clear that although the infant is well, the mother is not. The music becomes again insistent. No words are exchanged, but urgent resuscitation efforts begin. The mother dies (Figure 1). ${ }^{4}$

2 Pare Lorentz, FDR's Moviemaker: Memoirs and Scripts, Reno: University of Nevada Press, 1992, p. 124.

3 Bosley Crowther, 'Lorentz experiments', New York Times, 10 March 1940, p. 156.

4 For more specific details on the score see especially Robert F. Nisbett, 'Louis Gruenberg and the Fight for Life', Musical Quarterly (1995) 79, pp. 231-255. 


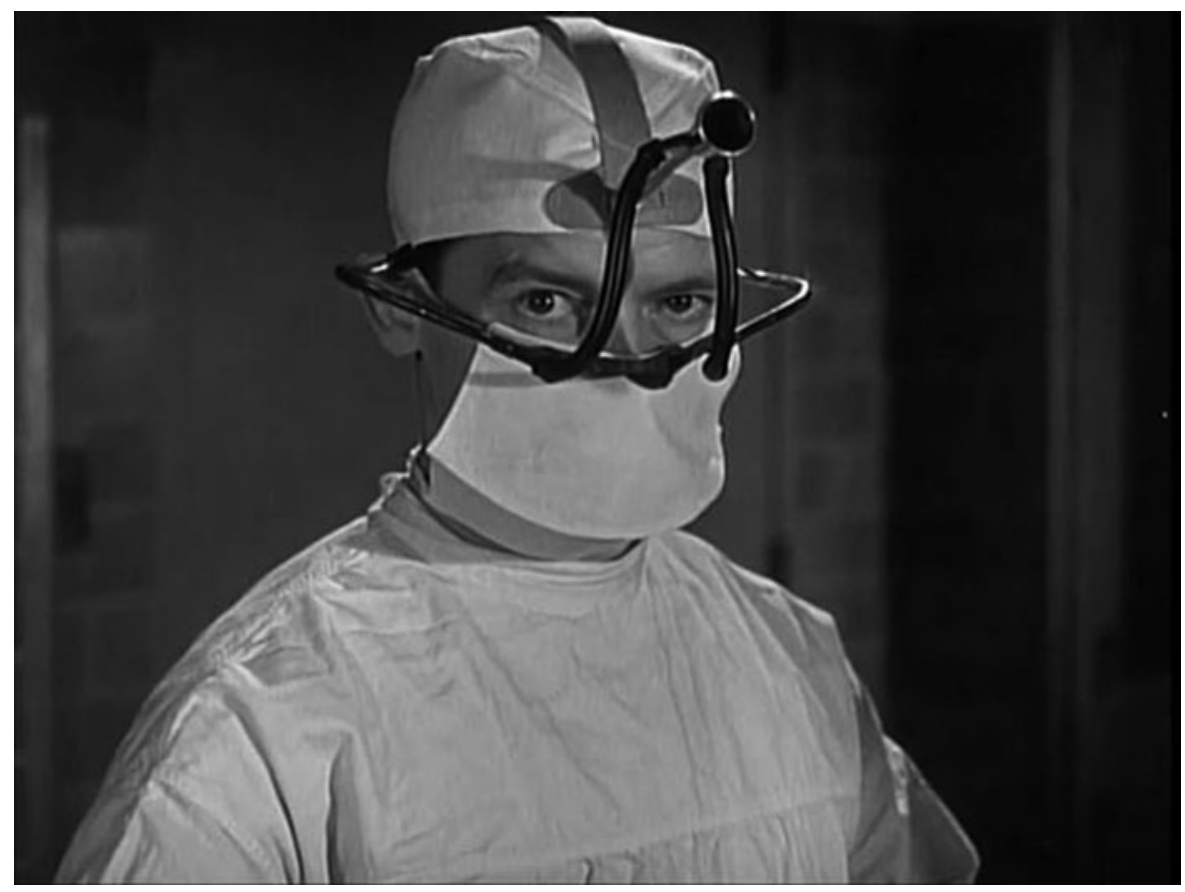

Figure 1. The doctor reacts to the baby's birth; the head attachment is a foetal stethoscope of DeLee's own invention. Screen grab from The Fight for Life (03:01).

This maternal mortality is the dramatic catalyst that propels the story's protagonist, Dr O'Donnell, to recognize the shortcomings of his own training in obstetrics: a reflection, the film confirms, of a larger crisis in obstetric care. O'Donnell's pursuit of obstetric expertise sets him on a path that ultimately leads him out of the hospital and directly to the doors of DeLee's Maternity Center. ${ }^{5}$ There he becomes an intern, learning DeLee's obstetric craft as he brings prenatal and obstetric care to the poorest women in the city. By the end of the film, his education on the streets is complete. In a scene whose drama mirrors the film's first, he confronts the haemorrhage of a mother whose baby he has just delivered. This time he knows what to do. With the quick, purposeful touch of the knowledgeable physician, O’Donnell saves his patient by administering a blood transfusion as she lies on newspapers covering the bed in her dilapidated home. What he could not do in the context of the modern, aesthetically sanitized hospital, he accomplished in the dirty, derelict tenement houses of Chicago's Bloody Twentieth.

The Fight for Life's depiction of childbirth in pre-Second World War America offers an odd coda to DeLee's life's work. At this point near the end of his career, DeLee had

5 For those interested in parsing the apparent contrast between DeLee's two approaches to childbirth - one at the Maternity Center, the other 'the streamlined birth' of his films - see Judith Leavitt, 'Joseph B DeLee and the practice of preventive obstetrics', American Journal of Public Health (1988) 78, pp. 1353-1360; and Caitjan Gainty, 'The pursuit of "happiness minutes": medical efficiency in the United States, 1910-1940', PhD dissertation, University of Chicago, 2012, esp. pp. 202-245. 
devoted himself to the pressing problem of maternal mortality, and was especially well known for his promulgation of antisepsis as its key solution. Indeed, this was what de Kruif had highlighted in his section on DeLee, fixing on this as the aspect of DeLee's work that had qualified him as a 'fighter for life' to start with.

The film did demonstrate some of the antiseptic practices DeLee had promoted: double gloving, careful attention to the sterilization of instruments, and, in the homes of the very poor expectant mothers who populated his Maternity Center, the copious use of newspapers in place of sterile towels, which DeLee promoted both for their ubiquity and for the fact that these had typically been there long enough to become microbially acclimitized (if they could not be antiseptic, they could at least reduce the risk to mothers in childbirth by being covered in familiar, and thus less offensive, germs). But though The Fight for Life was, narratively, a story about childbirth, the film's reception was neatly summarized by Frank Nugent, whose review for the New York Times suggested that this medical setting provided a 'slight story framework'. ${ }^{6}$ Another, writing for the Motion Picture Herald, more firmly characterized the film as possessing but 'a thin thread of plot'.

Perhaps in part the story's slightness can be attributed to the stringent production code in place at the time, which made finding a distributor for The Fight for Life quite difficult, and even led to its sporadic banning. ${ }^{8}$ More on the minds of its critics, though, was that the film's narrative portrayal of O'Donnell's transformation from ineffective practitioner to fighter for life seemed purposely superseded by the film's impressive visual commentary on poverty. And indeed, in many ways the choice to focus on the Maternity Center had less to do with its especially effective childbirth procedures for especially underserved women and more with the unprecedented access into the homes, lives and struggles of the very poor that its focus on home birth made possible. One reviewer noted that this film was of a piece with the two previous, except insofar as the focus had shifted from 'natural resources' to 'human resources'. ${ }^{9}$ Indeed, immediately after saving the life of the mother in the culmination of his real-world obstetric education, O'Donnell delivers an even more dramatic, Tom Joad-esque soliloquy on the grimness of being poor and alive. This monologue begins as an address to his colleagues, but then moves to voice-over, the technique which had typified Lorentz's two previous films. Here, set over a montage of America's poor, comprising footage from both Chicago's Bloody Twentieth and other slums across the Midwest, O’Donnell laments,

We teach them: the sun will make them strong against rickets and help fight TB. But where do we tell them to go for the green vegetables? Where do we tell them to move for the sunshine? ... They brought them into all our great cities from the hills and fields to build their machines and

6 Frank Nugent, 'The screen: Pare Lorentz again goes to fact for his drama in his new film, "The Fight for Life," at the Belmont', New York Times, 7 March 1940, p. 27.

7 Joseph F. Coughlin, “"The Fight for Life”: problems of parturition', Motion Picture Herald, 16 March 1940 , p. 34.

8 'Columbia, only major bidder, gets distribution of "Fight for Life", Motion Picture Herald, 25 May 1940, p. 12. See also Gerald R. Butters, Banned in Kansas: Motion Picture Censorship, 1915-1966, Columbia: University of Missouri Press, 2007, pp. 222-223.

9 'Film reviews: The Fight for Life', Variety, 6 March 1940, p. 18. 
roll their steel ... And left them in these shacks ... Here are bad teeth and tainted blood and infected lungs ... Here are damaged kidneys and cracked hearts and twisted legs ... [ Figure 2] ${ }^{10}$

Similarly, though we hear almost nothing from Lorentz's supporting actors, the 'women of the city' who quietly populated (and then repopulated) his film and whose 'cracked hearts' and 'damaged kidneys' O'Donnell so dramatically bemoaned, the little we do hear seems to suggest that they also recognized what the camera was really capturing. As Lorentz describes it in his autobiography, he and his crew had been accosted during production by the husband of one of the women whom they had filmed in the process of giving birth earlier. Unfazed by the fact that Lorentz had shot footage of his wife in labour, it was the realization that his 'abject home' had been immortalized on film that incensed this 'completely surly Polish gentleman'. Further, explained Lorentz, though 'he was unemployed, he said [that] public exposure of his terrible poverty would damage the lives of his family and himself and he could only allow it for fifty thousand dollars'. The problem was solved for Lorentz, however, when it became clear that the man had been 'absent from his home ... because he was still finishing time in Joliet Prison, where he had spent five years as a fence for receiving stolen property'. 11

This reading of the film drove nearly all of its contemporary responses. ${ }^{12}$ One critic noted that the film was 'typical of [Lorentz's] painstaking passion for reality', specifying not the obstetric details it captured, but the fact that the director had brought his crew into 'the crowded quarters of the center's tiny rooms, photographing people who had never seen a motion-picture camera before, working long hours, odd hours, always under the fluctuating dictates of reality'. ${ }^{13}$ The Times's Nugent added that the relative absence of the film's obstetric storyline was more than offset by the fact that the film laid bare so eloquently its 'grim reality', ${ }^{14}$ which was 'solidly built on human experience, on the tissue of life, on the beat of the human heart itself'. ${ }^{15}$

Even critics who had disliked the film, finding in it not 'reality' but melodrama, readily recognized its focus on poverty, selecting for criticism once again not its obstetric storyline, but its over-the-top performances of indigence. One critic noted the performances of the 'women of the city', writing that they 'present a drab and none too complimentary picture of expectant mothers, self-consciously aware of their impending predicaments', and found the film almost farcically depressing. ${ }^{16}$ For physicians in the audience, the performances of these indigent women qua actors was deemed especially unrealistic, and

10 Lorentz, op. cit. (2), pp. 207-208.

11 Lorentz, op. cit. (2), p. 132.

12 Only one implies that the film might be a call for socialized medicine. See the untitled commentary, Motion Picture Herald, 19 October 1940, p. 26. See also “"The Fight for Life" makes film history', Better Times (5 April 1940) 21, p. 1.

13 'Surveying the struggle: Pare Lorentz goes into the lists for his new film "The Fight for Life"', New York Times, 17 December 1939, p. 127.

14 Frank Nugent, 'Grim reality note', New York Times, 10 March 1940, p. 156.

15 Nugent, op. cit. (6).

16 Coughlin, op. cit. (7). 


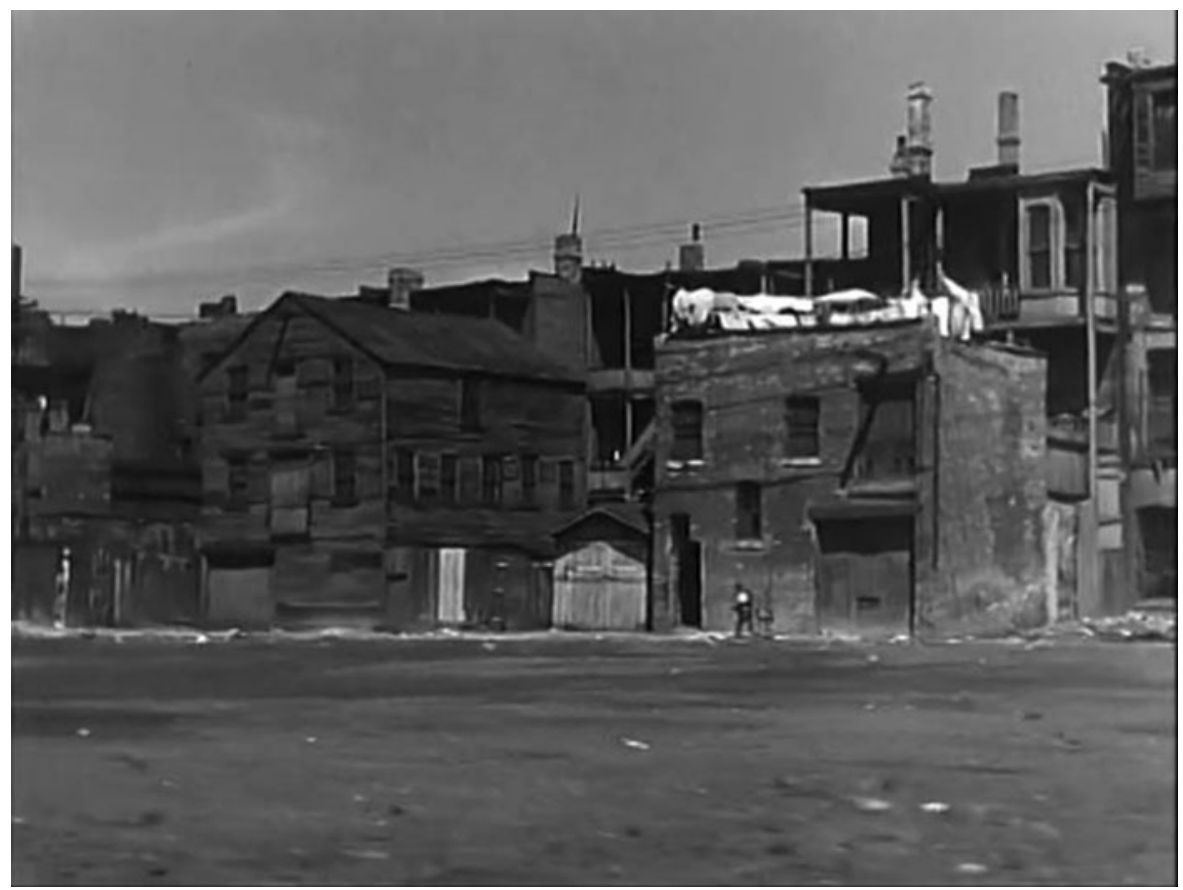

Figure 2. Images of poverty. Screen grab from The Fight for Life (43:01).

many wondered why the women had been told to act so glum. ${ }^{17}$ Even worse, this critic further noted, the film's focus on the grimness of poverty was so pervasive that it had even got to the professional actors, who 'plod through their paces as if the serious duties entailed in their performances had paralyzed their skill in running the range of human emotional expression'. ${ }^{18}$

This emphasis is not surprising for a film financed by and produced for the Roosevelt government, whose interests lay in reflecting the widespread results of the Depression and propagandizing the need for New Deal programmes to counter it. Health care was famously absent from the administration's programme of reform, but addressing poverty was one of its pillars. ${ }^{19}$ This was also the reading of the film that circulated in Congress. For critics of the Roosevelt administration, The Fight for Life offered lowhanging political fruit with which to lambast New Deal legislation. The 'smouldering resentment against the New Deal's spending on film' that emerged out of discussion

17 Letter from Nathaniel Davis III to DeLee, 13 January 1940, Papers of Joseph B. DeLee: Manuscript and Motion Pictures, Northwestern Memorial Hospital Archive (subsequently NMH), Box 49, Folder 2. The head of the AMA, Morris Fishbein, is quoted as commenting on this same issue in an untitled editorial on the film, Motion Picture Herald, op. cit. (12).

18 Coughlin, op. cit. (7).

19 On the FDR administration's views on health care see, for example, Jaap Kooijman, 'Soon or later on: Franklin D. Roosevelt and National Health Insurance, 1933-1945', Presidential Studies Quarterly (1999) 29, pp. 336-350. 
about The Fight for Life centred around the critique that the film, remarkably, traded depictions of poverty for meaningful intervention. ${ }^{20}$ As one newspaper noted,

Typical of the attack was that led by Congressman Albert J. Engel (Rep, Mich), who made the charge that the US Office of Education had supplied \$178,000 of WPA public relief money to make 'The Fight for Life' to show poor people in the slums eating from garbage cans, after seven years of New Deal squandering of public funds. ${ }^{21}$

Money that had gone to a film that turned poverty into an exhibition for the middle and upper classes, these opponents suggested, ought to have gone to alleviating it.

For others, however, the film's focus on poverty exposed a more specific weakness in the film: its critical departure from de Kruif's story, in which DeLee, and not O'Donnell, had been the featured fighter for life. One of Lorentz's correspondents, Lucille Driftmier Verness, not only noticed but actively critiqued the emphatic shift. Despite proclaiming herself to Lorentz as a 'genuine layman' in the medium of film, Driftmier Verness was no ordinary commentator: she had inherited from her mother, Leanna Field Driftmier, the popular radio programme/magazine pairing Kitchen-Klatter, which, under her helm, dispensed politically and socially astute commentaries for and about women's issues. From this vantage point, Driftmier Verness felt the film had cut its most critical element: DeLee himself.

In a long and eloquent letter to Lorentz, she wrote of her puzzlement as to the film's goals. 'Why was the picture made?' she asked.

That is the first question. Was it made to demonstrate the fact that death in childbirth is a brand of civilized murder almost totally inexcusable, or was it made to awaken people to the fact that a cleavage of staggering proportion exists between the science that delivers a child skillfully and then turns him over to a society where the words green vegetables, cod liver oil and sunshine are pure mockery? 22

Driftmier Verness opined that if it wasn't, it ought to have been made for the former of these, not only because this would make it consistent with de Kruif's narrative and DeLee's mission, but also because this was the more crucial commentary. Driftmier Verness continued,

When I left that theater last night, I thought this: if I were pregnant today I would be a million times better off if I lived on Halsted Street in Chicago and could have the services of the Maternity Center ... I know too that if I were in any one of a dozen different good-sized towns that I've lived in and were going to the hospital tonight to have a baby, I'd be a perfect candidate for death ... These are the doctors we have. And women should know it. ${ }^{23}$

To better inform his audience of this shocking truth, Driftmier Verness recommended that Lorentz restore to the story DeLee, who 'in [an] extra forty-five minutes ... could

20 'Fight in Congress over "Fight for Life" hits US documentary films', Motion Picture Herald, 30 March 1940, p. 13. See also 'Who'll have "Life”?', Motion Picture Herald, 6 April 1940, p. 9; and Coughlin, op. cit. (7).

21 'Fight in Congress', op. cit. (20).

22 Lucile Driftmier Verness to Lorentz, 4 October 1940, Pare Lorentz Papers, Franklin D. Roosevelt Library, Hyde Park, New York, Folder: Press Notices Scrapbook - The Fight for Life.

23 Driftmier Verness to Lorentz, op. cit. (22). 
have covered the field that I have discussed, and then your picture would have served the purpose that surely conceived it'. ${ }^{24}$

Yet, perhaps rather curiously, DeLee himself did not strenuously object to having been edited out of the film (though this absence was not perfectly accomplished: an observant colleague spotted an unintentional cameo, in the form of a small photo of the doctor hanging in the Maternity Center stairwell, which made its way into the film). ${ }^{25}$ Nor did he seem to share Driftmier Verness's perturbation at the film's relative reticence on the issue of dangerous childbirth. DeLee also did not seem to feel any sort of possessiveness about the use of his staff and the women served by the Center as the film's actors, and he did not comment extensively upon the fact that Lorentz had used his institutions.

Indeed, the obstetrician/source material seemed inclined to feel positive about the film, acknowledging in a letter to de Kruif that Lorentz 'had a very difficult task, - to present the actual workings of a highly technical medical subject in such a way that the public would understand it ... and he has done that as well, I think, as it can be done'. ${ }^{26}$ The motion picture, he felt, had 'caught the guiding spirit of the Center'. ${ }^{27}$ This was high praise. But it came with a postscript. To be exact, it was an addendum, titled 'Items for criticism (not in sequence)'. ${ }^{28}$

Enumerating thirty-one discrete problems he had with the film, much of DeLee's addendum details issues of continuity and technique. In item 2 , he complains about 'Two different women with identical dress'. In item 9, about a 'woman tak[ing] hold of the stove which was presumably hot. (The audience would think so)'. ${ }^{29}$ Item 15: 'on going to the Steel Mills scene bright daylight - arrive at night showing furnaces and their flames and glowing sky. Does it take so long to reach the patient?'30

The attention to detail carries on. He regards a 'dresser drawer' containing a newborn as 'too heavy to put next to a woman in bed, and too large'. Weighing in on the topic of the glumness of the women waiting in the clinic, he opined, 'the women in the clinic look $\ldots$ as if they were in an air raid'. He also noted for good measure that a doll used instead of a baby 'looks faked', and, 'doctor took lightest satchel and let nurse carry heavy one. Bad manners'. ${ }^{31}$

Only a few of these points of criticism, in fact, really called upon DeLee's obstetric expertise. Among these, items 25 and 26 corrected what DeLee took to be Lorentz's inaccurate statistics about maternal and infant mortality rates, ${ }^{32}$ and item 12 criticizes that 'a woman who suddenly goes blind needs immediate treatment'. Even this,

24 Driftmier Verness to Lorentz, op. cit. (22).

25 Davis to DeLee, op. cit. (17).

26 DeLee to Paul de Kruif, 15 January 1940, NMH, Box 49, Folder 2.

27 DeLee to de Kruif, op. cit. (26).

28 Joseph DeLee, addendum to letter to Paul de Kruif, 15 January 1940, 'The Fight for Life: items for criticism (not in sequence)', NMH, Box 49, Folder 2.

29 Addendum, op. cit. (28).

30 Addendum, op. cit. (28).

31 Addendum, op. cit. (28).

32 Addendum, op. cit. (28). Lorentz, however, denied these inaccuracies. See Lorentz to DeLee, 25 March 1940, NMH, Box 49, Folder 2. 
however, is followed up not by a medical explanation as to why this is so, but by the concern that 'the audience is not satisfied with the doctor's assuring her everything will be all right.' As if to further clarify that DeLee's concern here is filmic and not medical, he added that it is for this reason that the scene 'has no punch'. ${ }^{33}$

DeLee's rather methodical analysis came not from his experience as a well-known obstetrician, but as a seasoned filmmaker. Indeed, as DeLee was fond of reminding potential financial backers for his own films, one would have to go all the way to Hollywood to find his equivalent in expertise and training. ${ }^{34}$ (Meanwhile, went one apocryphal tale, 'FDR's Filmmaker' had only ever been to Hollywood to 'scrounge up stock footage' of 'land rushes or cattle herds'35). Though self-aggrandizing, DeLee was also, as he suggested, both trained and experienced. He had taken it upon himself at the beginning of his foray into film more than a decade earlier to acquire professional equipment and to enlist the help of experts to teach him this new craft. By 1940, he had produced perhaps a dozen films (well more than the two that Lorentz had to his credit), including several 'talkies', the first of which debuted in 1930 and was written up in the Detroit Times. ${ }^{36}$ In fact, he had also over this period written a fictional script of his own, which he had sent for consideration to Paramount and RKO, promising them that he would be happy to help with its production. ${ }^{37}$ And though he had largely retired from his obstetric practice, DeLee was still actively engaged in filmmaking.

Though a few of DeLee's complaints do seem to stem from the kind of artistic differences a background in filmmaking might suggest, for the most part DeLee found devilry in the detail. Perhaps because the maternal death scene with which the film opened took place on one of the very birth room 'sets' that DeLee had so carefully designed for his own films, DeLee returned to this scene three times in his addendum. It was a place he knew well - cinematically - and its consequent perceived misuse by Lorentz must have particularly irked. He wrote to de Kruif,

Birth room scene at hospital - no students which would have given it dramatic power and the individuals in close up cut-ins could have reflected in their faces what was going on - concentration, horror, surprise; also wrong birth room was selected. Disconcerting background, my movie dolly shows with empty seats. A fine scene spoiled. ${ }^{38}$

Though DeLee focused here on perceived errors of 'dramatic power', it is the final elements - the wrong room, the disconcerting background, the empty seats and perhaps especially the errant movie dolly - that seem finally to push the scene into the category of 'spoiled'. Echoing the majority of his items for criticism, DeLee's dismay even here

33 Addendum, op. cit. (28).

34 Joseph DeLee, 'The motion picture in obstetric teaching', unpublished manuscript, NMH, Box 49, Folder 3.

35 Aljean Harmetz, 'Hollywood hails Lorentz, documentary pioneer', New York Times, 22 October 1981, p. C22.

36 Vera Brown, 'Specialist employs “talkie” to depict operation', Detroit Times, June 1930, NMH, Box 49, Folder 4.

37 Joseph DeLee to Albert Lasker, undated letter (c.1932), NMH, Box 49, Folder 6.

38 Addendum, op. cit. (28). 
was focused on Lorentz's apparently shocking inattention to detail - not obstetric, but cinematic.

In some cases, these criticisms coincide with those of the film's more negative reviewers, who had found the film's melodramatic portrayal of poverty to be a bit much. And for some of its physician viewers, the problem with the film was its misappropriation of the 'reality' of obstetric work. But DeLee's criticisms crucially point in another direction, concerned less about what the film showed than about how it showed it.

Perhaps unsurprisingly, as he told both de Kruif and Lorentz, DeLee wished that he had been consulted, not for his obstetrical but for his filmmaking expertise. ${ }^{39}$ Summing up his correspondence and conversation with Lorentz on these issues, DeLee wrote to de Kruif,

Following your (unneeded) request to overlook certain temperamental vagaries in the Director I was as friendly as I knew how to be but since I felt that a better picture could have resulted if he had accepted advice - or even some slight guidance ... I told Lorentz that I wish he had consulted me. I said, 'Lorentz, you have great dramatic instinct and power and you have done very well with the subject matter but if you had let me help you, together we could have produced a really effective picture. ${ }^{30}$

In some ways, this comes directly to the crux of the issue: in DeLee's view, the film was not 'effective'. The reasons for its ineffectiveness centred tellingly around these missed details and incoherencies. And though in one sense this seems merely to register DeLee's feelings about the film, it is worth lingering over this term 'effective', since in DeLee's own filmmaking craft it carried a more exceptional and particular set of requirements and significances.

\section{Joseph DeLee, filmmaker/streamliner}

DeLee categorized the majority of his films as aimed at medical training, a task which they do in fact take on. And they are executed with exceptional style. Many open on DeLee lecturing on a particular obstetric topic, often illustrated with slides and including anatomic models upon which DeLee could demonstrates his techniques to an audience of students. But they also moved from location to location; the same audience of students who listen to his lecture in the lecture hall shortly thereafter appear with DeLee in his birth room, to see the discussed procedure performed live. It is the viewers who have the best view, both of the procedures and of DeLee himself, and surely these films were meant to take advantage of the roundly held belief at the time in the pedagogic value and possibilities of film. ${ }^{41}$ More importantly, however, these films demonstrate the way in which DeLee's particular filmmaking craft became a key technology in his

39 Letter from DeLee to Lorentz, 1 April 1940, NMH, Box 49, Folder 2.

40 Letter from DeLee to de Kruif, op. cit. (26).

41 See e.g. Kirsten Ostherr, Medical Visions: Producing the Patient through Film, Television, and Imaging Technologies, New York: Oxford University Press, 2013; Devin Orgeron, Marsh Orgeron and Dan Streible (eds.), Learning with the Lights Off: Educational Film in the United States, New York: Oxford University Press, 2012. The DeLee films are divided between the Northwestern Memorial Hospital Archive and the 
iteration of a contemporary birth procedure, widely known, by practitioners and in the press, as the 'streamlined birth'.

When it is described now, the 'streamlined birth' is largely viewed as coextensive with the medicalized birth: hideously invasive, messy, complicated and dangerous. Streamlined birth procedures required at least four different drugs - to put mothers into 'twilight sleep' so that they would neither be aware of nor remember the birth; to make the labour pain-free; to induce the very labour the first set of drugs had so effectively forestalled; and, after the birth process was complete, to re-contract the uterus. In addition, there was nearly always an episiotomy incision to be made (and stitched up moments later), forceps, suction catheters and other implements, and finally the agents of asepsis: shaved vulvas, sterile gloves and pristine surfaces. Because these last two in particular were not always available in every hospital and because of the more general likelihood for things to go awry amidst the complicated machinery of the streamlined birth, there was a great deal of death associated with it, mostly arising, perhaps unsurprisingly, from the greater risk of infection such an interventionist procedure imposed. And instead of falling, maternal mortality rates over the first decades of the twentieth century trended upward. ${ }^{42}$

At first glance, the draw of this procedure stemmed largely from the cultural resonance of streamlining more generally. The concept of streamlining had first emerged out of late nineteenth-century engineering, where it referred specifically to the theoretical 'stream lines' or 'lines of flow' that parted around, and then moved parallel to, bodies in motion. Engineers first used it in blueprints for air, land and sea vehicles, designing them with rounded edges and tapered tails to reduce drag and facilitate movement in a way that prolonged engine life without sacrificing speed. By the early 1930s, streamlining had found new applications. Industrial designers like Norman Bel Geddes, who is widely credited (and indeed credited himself) as the father of the 'streamline moderne' design movement, saw in the blueprints of the transport industry a model not only of function, but also of modern aesthetics. Thus the frictionless streamlined look was appropriated for lipstick, pencil sharpeners, lamps and vacuum cleaners, and even hospitals, department stores, diners and other structures - objects with little apparent need for the functional aerodynamicity that streamlining brought to vehicles.

Rejecting the frillier adornments of art deco, industrial designers encased everyday objects in egg- or teardrop-shaped bodies adorned sparely with 'speed whiskers', giving them the appearance of movement. Contrasted with the functionalism that was in full swing in Europe at the time, these shiny facades still seemed an unnecessary ornamentation, the sign of a culture that promoted style over substance. Indeed, in the mid1950s, the industrial designer Henry Dreyfuss, himself renowned for his contributions to

University of Chicago Department of Obstetrics and Gynecology Archive. Some have been digitized by the National Library of Medicine.

42 See Joseph DeLee, 'The maternity ward of the general hospital', Modern Hospital (1926) 6, pp. 67-72; DeLee, 'What are the special needs of the modern maternity', Modern Hospital (1927), 28, pp. 59-69; DeLee, 'How should the maternity be isolated', Modern Hospital (1927) 29, pp. 65-72. See also Joseph DeLee and Heinz Seidentopf, 'The maternity ward of the general hospital', Journal of the American Medical Association (1933) 100, 1, pp. 6-14. 
the streamline design movement two decades earlier, characterized the movement as a misstep in the history of modernist design. Dreyfuss was especially unhappy about the ways in which form not only was divorced from function, but seemed to emphasize and indicate a function of an entirely other form. His criticism of Raymond Loewy's iconic 1934 streamline design for a pencil sharpener pointed to the glaring dissonance between its acclaimed aerodynamic form and its basic functional inability to move: 'it couldn't get away', he scoffed, 'if it tried'. ${ }^{43}$

In its heyday, however, streamlining was not just about keeping up the appearance of modernity. Instead, the shape of streamlined consumer goods offered visible evidence of their functional fitness in the increasingly turbulent environments that surrounded them. This was the era of the Dust Bowl, when particulate matter pervaded the food, homes and lungs of those living in the American heartland, even reaching the East Coast with the most violent of the black blizzards. It was also the era of anti-germ crusades, when health professionals criss-crossed the country extolling the virtues of clean hands and sanitized surfaces. ${ }^{44}$ The rounded, sealed chrome, glass and plastic that now surrounded everyday objects protected their internal complexity from the dangers without, allowing these objects to part the invisible and ubiquitous sea of germs and dirt that was always flowing around them, and thus to achieve something akin to the 'smooth flow' of their vehicular counterparts. ${ }^{45}$

As perhaps this makes clear, the protective consumer streamlining aesthetic had an important natural analogue: the human body. In his Itinerary of a Breakfast, the physician and rather populist health writer John Harvey Kellogg reflected on human digestion exactly in this way, as a system of transport which worked when it avoided constipation and achieved smooth flow. ${ }^{46}$ All but rejecting that digestion's role was one of energy provision, Kellogg instead focused on the engineering of the transport of food through, and waste out of, the human body, likening it, in many ways, to its contemporary, the railway, with fibre as its conductor (Figure 3). ${ }^{47}$

These ideas about the digestive system spelled out new characteristics of streamlining that held significance for American culture. As Kellogg warned, lack of movement posed a danger both to productivity and to the body itself. Catalysed by germ theory, this latter worry concerned the loitering of dangerous waste matter in the body. ${ }^{48}$ Constipation was thus not just problematic for the discomforts and dysfunctions associated with the stoppage of flow. It held the threat to harm and disable other bodily systems as well. Though these systems had their own function, they were linked in many ways,

43 Henry Dreyfuss, Designing for People, New York: Simon and Schuster, 1955, p. 74.

44 See, for example, Nancy Tomes, The Gospel of Germs: Men, Women, and the Microbe, Cambridge, MA: Harvard University Press, 1999.

45 See especially Christina Cogdell, 'Smooth flow', in Susan Currell and Christina Cogdell (eds.), Popular Eugenics: National Efficiency and American Mass Culture in the 1930s, Athens: Ohio University Press, 2006, pp. 217-248; and Cogdell, 'Products or bodies? Streamline design and eugenics as applied biology', Design Issues (2003) 19, pp. 36-53. See also Ellen Lupton and J. Abbott Miller, The Bathroom, the Kitchen, and the Aesthetics of Waste: A Process of Elimination, New York: Kiosk, 1992, p. 2.

46 John Harvey Kellogg, The Itinerary of a Breakfast, New York: Funk and Wagnalls, 1919.

47 Kellogg, op. cit. (46), p. 37.

48 Tomes, op. cit. (44). 


\section{Normal Itinerary of a Meal Passing Through the Alimentary Subroay}

\section{TIME TABLE}

\begin{tabular}{|c|c|c|c|}
\hline Arerval & Gıтs & Station & Defartuex \\
\hline 8:00 A.x. & $\begin{array}{l}\text { No. 1. Food Administrator } \\
\text { No. 2. Inspector } \\
\text { No. 3. Food and Water }\end{array}$ & Mouth & $8: 30$ A.M. \\
\hline $8: 30$ A.x. & $\begin{array}{l}\text { No. 4. Stomach } \\
\text { No. 5. Bowel-Pylorus }\end{array}$ & Stomach & $12: 00$ Noon \\
\hline 12:00 Noon & No. 6. Ileo. Sphincter & Small Intestine & 4:00 8... \\
\hline 4:00 r.x. & No. 7. Colon-Ileo. Valve & Cecum & $6: 00$ P.M. \\
\hline 6:00 r.x. & No. 8. Reversing Gate & Transverec Colon & $8: 00$ r.x. \\
\hline \multirow[t]{2}{*}{ 8:00 8.x. } & No. 9. Ejector & Pelvic Colon & 10:00 P.य. \\
\hline & No. 10. Exit & Rectum & $10: 00$ r.x. \\
\hline
\end{tabular}

\section{SPECIAL NOTICES}

Train Lato: Held at Stomach Station for 2 hrs. Bowel Gate (No. 5) refused to open.

Losing Timo: Wreck at Colon Gate (No. 7). Ileocecal valve refuses to close, track obstructed with rubbish. 8 hours late.

Losing Timo: Collision with heavy train backing up. 10 hours late.

Losing Timo: Obstruction on the track. Ejector Gate (No. 9) refuses to open. 20 hours late.

Losing Timo: Serious obstruction. Track buried with rubbish. 35 hours late.

Train arrives at last, after clearing track with dynamite (castor oil), forty hours late.

(This is the usual program when the bowels move only once a day or occasionally.)

Figure 3. 'The digestive time table', from John Harvey Kellogg, Itinerary of a Breakfast, New York: Funk and Wagnalls, 1919, p. 37. 
not least in their common vulnerability to infection. The quick hastening of matter that was at the centre of the digestive system's purpose was prophylactic in character, keeping the rest of the body free to function normally.

There were clear parallels between this view of digestion, as primarily about flow, and childbirth, a bodily function that was even more explicitly and singularly centred on movement through and out of the body. Yet in comparison to digestion and in seeming contradiction to its very function, childbirth seemed to be characterized by stoppage, by near constant obstetric constipation, with a flow that, when it occurred, was laborious and painful. It was well known that dangerous complications could occur when the foetus's short journey through and out of the birth canal was stalled, and a long, drawn-out delivery threatened both the health and life of both infant and mother. But there was no fibre-like fix to counteract this stoppage. And, ominously, many obstetricians considered the problem here to be the modern body itself, marking it physiologically, psychologically, but also ideologically, as an emblem of modernity's implications and the greatest impediment to its own natural function. The streamlining solution, therefore, lay in circumventing the process altogether.

Though the kind of circumvention that streamlining implied in the context of birth has been difficult retrospectively to parse, contemporary accounts are quite clear on the ways in which the streamlined birth differed from, and improved upon, natural birth. A 1938 Reader's Digest article, entitled 'Our streamlined baby', offered a useful articulation of public expectations around this birth process. Here the author contrasted the birth of his first daughter, in 1916, with that of his second, in 1938, writing that his second daughter had been born the 'easy, painless streamlined way', with his wife able to plan the process in consultation with her doctor, such that her labour and delivery became the culmination of a grand day out. ${ }^{49}$ After taking in a matinee and then an early dinner, his wife was to go to the hospital and check in, with the promise that the next day, she would not only have had her baby but would have no memory of it. ${ }^{50}$ The baby would just be there, to cap off the preceding day of entertainment with a lovely little gift, which she could learn to love in the hospital and then, after a few weeks of rest, take home. His wife was so pleased with her streamlined birth that she gushed, 'Why, I wouldn't mind having another baby next week if that's all there is to it.' 51

Like other articles that espoused the streamlined birth, the key feature here was the forgetting of childbirth, its elision into the banality of life or, in this case, the extraordinary fun of a grand day out. ${ }^{52}$ It was in this narrative that a key characteristic (slightly shifted in focus from its much-maligned predecessor 'twilight sleep') of the streamlined birth manifested itself. ${ }^{53}$ Even if birth could not be deconstipated and sped up along the

49 J.P. McEvoy, 'Our streamlined baby', Reader's Digest, May 1938, pp. 15-18, 15.

50 McEvoy, op. cit. (49), pp. 15-16.

51 McEvoy, op. cit. (49), p. 16.

52 See, for example, Betty MacDonald, The Egg and I, New York: Harper \& Row, 1945.

53 On the political currency of twilight sleep see Jacqueline Wolf, Deliver Me from Pain, Baltimore: Johns Hopkins University Press, 2009, pp. 44-72; Judith Walzer Leavitt, 'Birthing and anesthesia: the debate over twilight sleep', Signs (1980) 6, pp. 147-164; Patricia Stokes, 'Purchasing comfort: patent remedies and the alleviation of labor pain in Germany between 1914 and 1933', in Paul Betts and Greg Eghigian (eds.), Pain 
body's material plane, it could certainly achieve these goals along the body's perceptual plane. The pharmacologically induced collapse of obstetric time that the drugs associated with twilight sleep provided came to be read as streamlining's efficiency mechanism at work; it metaphorically 'speed-whiskered' birth, editing together for a new mother a totally different kind of birthing, in which the painful and dangerous events that took place between dinner and the gift of a new baby simply disappeared.

DeLee did not, especially by the end of his life, consider himself to be a streamliner, and he eschewed as unsafe most forms of the procedure, especially those caricatured by the senseless whirling around of The Fight for Life's opening scene. Yet, perhaps more than most, DeLee's birth procedures epitomize the streamlined birth's hallmark prioritizing of perception as the place upon which streamlining did its work. The women who underwent DeLee's process were not only bestowed the usual experience of forgetfulness, they were also 'returned' surgically to what he considered a perfect anatomic state, to 'virginal conditions'. ${ }^{54}$ This return to virginity spells out in even larger letters the perceptual priorities of streamlining in DeLee's process, since with this act he extended the illusion that birth and even pregnancy had not taken place in the material world. In doing so, the streamlined birth was reimagined, from a procedure that confined its working to the immaterial, more ethereal realms of memory and imagination, to one that prioritized that space as more critical than, because capable via his editing hand of transcending, its material, physiologic counterpart. Even prior to taking up filmmaking, DeLee thus demonstrated both a characteristic attention to detail and an understanding of the need for manipulation in the material realm in order to achieve effectiveness in the obstetric streamlining frame. And from early on, DeLee's procedures built upon the already cinematic nature of the streamlined birth, extending and expanding it, via a kind of manipulation that resembled film editing: a snip here, a stitch there could produce a more perfect illusion, and thus a more perfect, a more effective, result.

Though DeLee narrated his shift to motion pictures merely as the adoption of a useful medium by which his birth techniques could be further disseminated, nonetheless these films extended and perfected the logic of streamlining, doubling down on perception as the realm within which birth could be made safer and better, more effective, and inviting into this realm not only expectant and new mothers, but also anyone who viewed his films. What film and the motion picture camera provided as technologies of streamlining was the chance to redesign birth entirely: to provide, via editing, animation and special effects, an even more convincing collapse of obstetric time; via the manipulation of film speed, the perfect pacing of this smooth flow; and via the transference of this experience to celluloid, an impenetrable prophylactic shell that could speed-whisker the dirt and germs away. Remaking birth shifted to emphasize the new kind of imaginary space of streamlining that film uniquely made possible: interventions not in the body itself, but

and Prosperity: Reconsidering Twentieth-Century German History, Stanford, CA: Stanford University Press, 2003, pp. 61-94.

54 Joseph B. DeLee, 'The prophylactic forceps operation', American Journal of Obstetrics and Gynecology (1920) 40, pp. 34-44. See also the description of DeLee's methods in Leavitt, op. cit. (5), p. 1353. 
in the production of that body - the perception of that body - on film. The 'forgetting' of women who underwent the streamlined birth, the already cinematic elision of time and space that formed their experience of birth, not only was given new and more perfect articulation here by DeLee; it also extended and reiterated the effectiveness of birth that mothers had experienced, now for a much larger audience.

\section{A little bit of Hollywood in the operating room}

Just as his non-filmic streamlined birth had relied on his detail-oriented and painstaking process to control and perfect streamlining's hallmark elision of maternal time, so too here DeLee's films are marked by a similar obsession, this time, though, in altering the perception of any and all who viewed his films.

This meant that he needed the best equipment. DeLee was constantly raising money from the ranks of his past and current patient rolls, using their connections too to press for the equipment he desired (notably, from the production company Essanay, which had recently closed). ${ }^{55} \mathrm{He}$ also enlisted the experts of Eastman Kodak in his venture, in part to help him professionally outfit one of the birth rooms in his Chicago Lying-In Hospital. Shortly after, DeLee expanded this room into a 'complete moving picture studio', equipped with scaffolding and tripods to support multiple camera angles, as well as improved equipment to more effectively and realistically light his 'set' (Figure 4). ${ }^{56}$ DeLee later added a sound studio to expand into 'talkies', and he took many trips to Hollywood to 'go through the studios to inspect their big equipment and cross-examine cameramen'. ${ }^{57}$ It was these trips that convinced DeLee that he was equal in training and technical expertise to the best producers in Hollywood. ${ }^{58}$

Because these films had to retain their attachment to the non-filmic world of childbirth in order to achieve the kind of streamlining effectiveness he sought, rather than employ actors, he - as Lorentz would later also do - populated his films with his own employees at the Chicago Lying-In Hospital. DeLee's associate, the obstetrician M.E. Davis, served as the director for many of these films, occasionally serving as DeLee's foil, whose urgent request for DeLee's help is the premise upon which the film moves from lecture theatre to birth room. ${ }^{59}$ Other employees were pressed into service as part of his production crew. Indeed, the only non-medical staff whom DeLee employed was the cameraman whose duties were also explicitly, like DeLee's own, likened to those of his peers in Hollywood. ${ }^{60}$

55 This arrangement is detailed in DeLee's correspondence with Mrs John A. Spoor, 30 December 1927, NMH, Box 49, Folder 2.

56 DeLee to R.W. Green, 10 January 1928, NMH, Box 49, Folder 2.

57 Herman Liebes, recounting his association with DeLee to Helen Joseph, 28 April 1963, NMH, Box 49, Folder 2.

58 DeLee, op. cit. (34).

59 Joseph DeLee (dir. and prod.), Science and Art of Obstetrics: Forceps and Episiotomy (1934).

60 DeLee, op. cit. (34). 


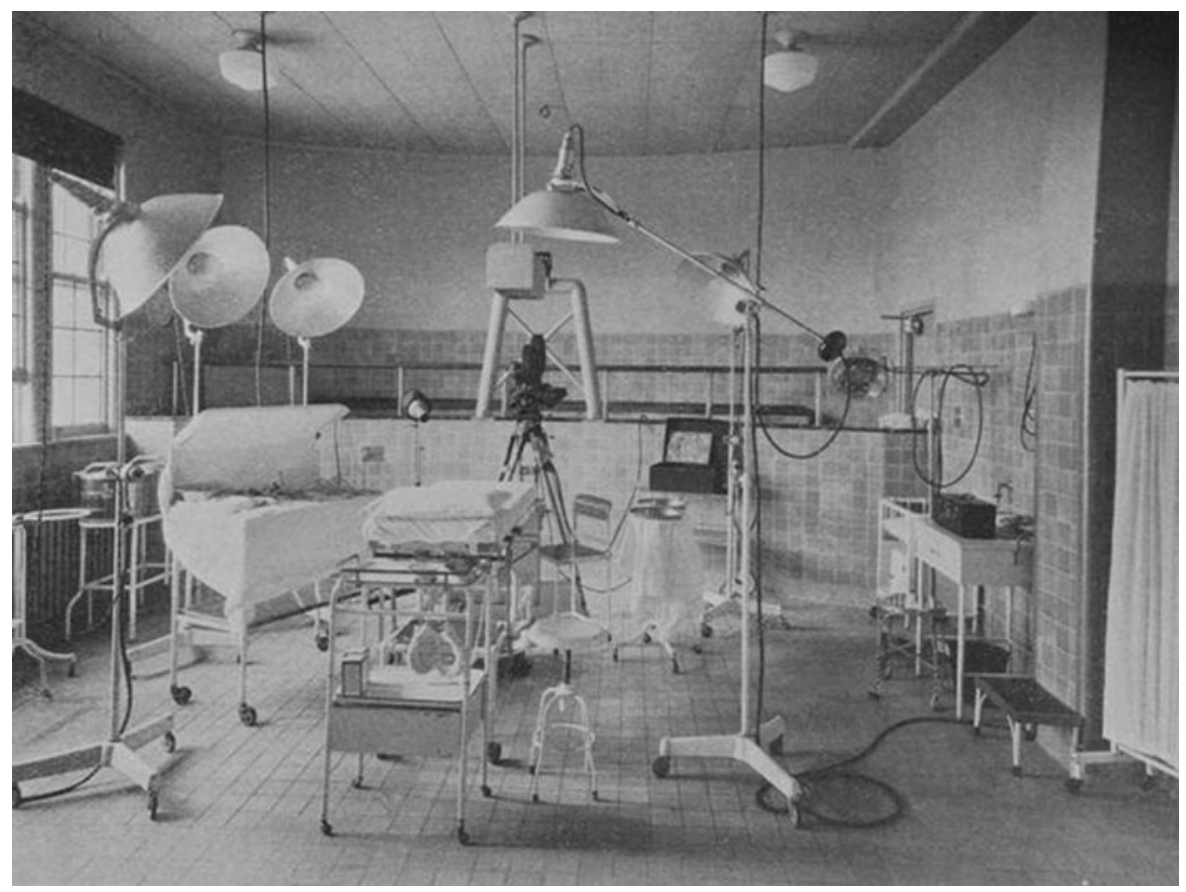

Figure 4. DeLee's birthing room/movie set in his Lying-In Hospital, c.1933. Photograph from Joseph DeLee, 'Sound motion pictures in obstetrics', Journal of the Biological Photographic Association (1933-1934) 2, pp. 60-68, 65, used with permission of the board of directors of the Journal of Biocommunication.

And because the details of the film had to present exactly the right streamlined perception, it was DeLee himself who took on the heaviest workload. In addition to acting in his own films, DeLee was the producer, scriptwriter and editor, and also kept for himself the tedious preparations of all of the title cards with exacting instructions to the printer as to how they should be prepared (Figure 5).

DeLee could not, of course, act out all of the parts himself, but he insisted that his staff hold both table reads and filmed rehearsals so that all could have the opportunity to master their roles in any given film under his watchful eye. ${ }^{61}$ This was especially important once DeLee began filming his talkies, which he introduced into his repertoire in 1929. And, as DeLee did not film scenes necessarily in consecutive order, it was also important that his staff attend to changes in the lines, which might occur daily, reflecting the unexpected shifts in the filming schedule which changed according to the schedule determined by his 'stars'. These were, of course, the women of his Chicago Lying-In Hospital and their babies.

Lying etherized and numbed on the table, the mothers at DeLee's hospital would hardly know that they had been filmed. Though DeLee warned those interested in

61 DeLee, 'Sound motion pictures in obstetrics', Journal of the Biological Photographic Association (19331934) 2, pp. 60-68, 62-63. 


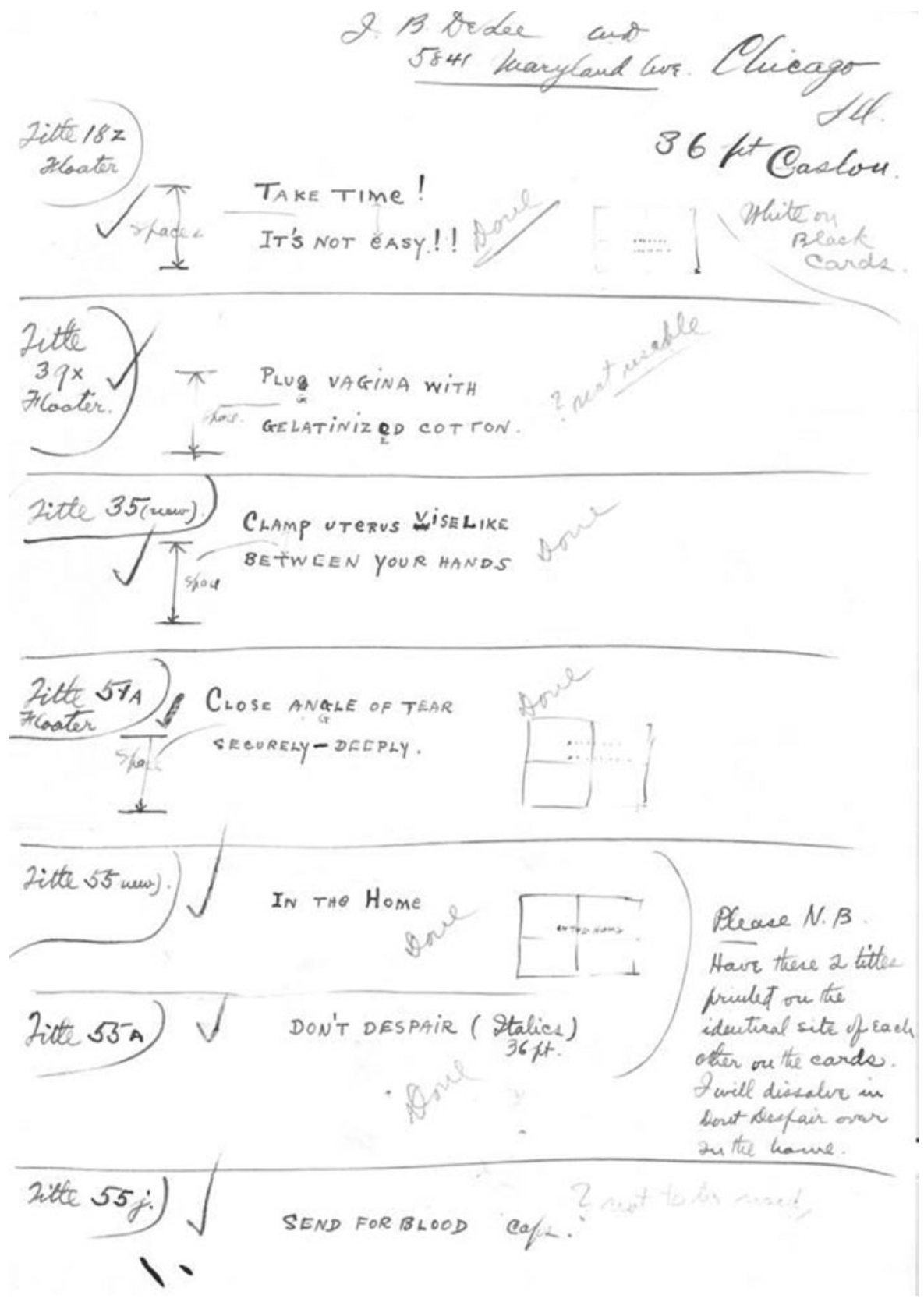

Figure 5. A title card with specific details for printing, undated. Northwestern Memorial Hospital Archive, Box 49, Folder 1. 
medical motion picture-making that the technology he employed might result in the occasional mild superficial burns, raised temperature, quickened pulse and 'probably ... also some chemical and hormonal changes in the system, produced by the light rays', ${ }^{62}$ each typically woke up the next day with only a healing episiotomy and a baby. Multiple expectant mothers and their babies were used in the filming of a single motion picture, which destroyed any possibility of a continuous storyline of the lives of these two individuals.

DeLee suggested that the use of multiple women and babies to make one film was largely just about practicalities; he simply could not capture in one take everything that one needed in order to see what the procedure looked like, especially because of the many variables and complicating factors that had to be controlled. He wrote in an instructional article to other budding medical filmmakers,

If awake, the patient must cooperate, and if asleep, the anesthetic must be a good one, and it may not be unduly prolonged while getting the picture-since anesthesia always has an element of danger. For this reason only a part of the total number of scenes may be taken on one patient. Often complications (not photographic) occur during the operation which ruin all the 'takes' and this is particularly true of obstetrics - notoriously a practice of surprises. The assistants and nurses, too, create many complications - unless they are experienced in operating before the camera, and not seldom the cameraman himself will ruin an otherwise perfect performance. I had to do 15 caesarean sections to make one picture. Everyone, including myself, made mistakes. ${ }^{63}$

But in fact the use of multiple women and babies to create a single performance points to a key character of DeLee's 'perfect performance' of the streamlined birth on screen, which, in a way akin to his restoration of 'virginal conditions' to complete the illusion that birth had not occurred, folds a more ordinary meticulous attention to detail into an intensive, interventive programme of manipulation. From these fifteen procedures, DeLee produced one film that presented a composite of women and babies that offered a more perfect performance than any single birth experience could have produced on its own. The transformation of perception here is, of course, significant, since in his non-filmic streamlined birth practices there was only ever one woman and, if not one baby, then certainly no more than a few babies at a time. The possibility of stringing performances together, however, not only put a new spin on the elision of maternal time, but also shifted the subject of perceptual manipulation from mother to viewer. In so doing, DeLee extended and expanded on the promise of streamlining in childbirth to manipulate perception, to create an illusion that depended on the elision now of women and babies more generally. This suggests something of streamlining's aesthetically focused prophylactic power, now instrumentalized by film. In this one composite life exist all individual lives; the safety of this one reflects the safety of them all. Even further, it suggests an aesthetically catalysed, perceptual kind of immortality. A composite mother produced by film, after all, is a mother who lives on: at least as long, that is, as the film that encases her.

62 DeLee, op. cit. (61), p. 62.

63 DeLee, op. cit. (61), p. 62. 
Whatever the particular reading given to DeLee's use of composite women, this points toward the intrinsic usefulness of the filmmaker's toolkit in performing the work of the streamlining physician. DeLee made full use of the filmmaker's tool, early on recognizing the need for animation, which he folded into the more general category of his 'trick camera' work. In one instance, in which DeLee desired to show proper use of the forceps, he considered the possibility of including a cautionary image of a baby's head too firmly grasped in the forceps, which he proposed to illustrate through the use of a word balloon extending from the baby's mouth, containing the word 'OUCH!!' in full capitals and with two exclamation marks. ${ }^{64}$

DeLee's focus on creating the 'perfect performance' was so all-encompassing that even babies were not exempt. In order to re-create the authentic sound of the 'first cry of the neonatus', DeLee brought infants into the sound studio. Because their cry was not as 'gurgling' as that of the newborn, he had to improvise a bit, 'drop[ping] a teaspoonful of water into [the baby's] mouth' while it was crying to create the right sound. The effect of this, DeLee thought, 'was perfect', and, he commented for those who cared, 'the baby was none the worse for its experience, which is a very common one for babies during natural delivery'. ${ }^{65}$

The purpose of these films was never - not even when they are considered in the context of training films - to document the arrival of life, but to intervene in that arrival, with film as a key tool. To use the employees and patients of his hospitals in these films at once tethered streamlining to a world of lived experience and remade that tie. In editing women in and out to create one perfect film of birth, in adding babies who say OUCH!! or gurgle as the script demands, in demanding and getting the best performances no matter the number of takes, DeLee was able to build upon and give ultimate expression to what had been out of reach in his non-filmic streamlining practices.

As the real-life streamlined birth also had, DeLee's films redirected expectations about the function of childbirth, as achievable via the perceptual, in this case cinematographic, efforts of streamliners. What one sees in the end is not the backbreaking and tedious work of creating a film, nor the backbreaking and laborious work of delivering a baby, but the final, streamlined product, the film itself. What remained was not a representation or a capturing in any kind of conventional way of the material, nonfilmic experience of birth as it happened, but a new, hyperreal rendering that played on the healing power of perception as it could be achieved newly, completely and fully by film. Whether or not the birth had actually happened in the way that had been captured on film was to misunderstand the nature and power of the streamlined birth, which worked when one prioritized and believed in the power of perception, however manipulated, to re-create childbirth as perfect, natural, safe and effective.

64 'Trick movies', undated, NMH, Box 49, Folder 1.

65 De Lee, op. cit. (61), p. 67. 


\section{The Fight for Life redux}

It is worth recalling DeLee's complaint to de Kruif over his directorial absence from The Fight for Life, his feeling that if Lorentz had let him help, they could have 'produced a really effective picture'. ${ }^{66}$ In this lamentation is expressed not just a simple dismissal of the work as simply not very good, but the more telling and specific suggestion that effectiveness was the right measure upon which to evaluate this, and possibly all, film. It is the reaction from one filmmaker, for whom the camera existed as a medical technology with rules and requirements situated firmly in getting the details right and effective pictures constituted by 'perfect performances', to another, who not only ignored these rules, but seemed never to have heard of them. In running roughshod over the film's details, in two women wearing identical dresses; in inadvertent dolls that snuck their way into the picture; in hot stoves that, when leaned on, did not even provoke an 'OUCH!!'; in death pallors that failed to pale; and in all the myriad ways Lorentz failed DeLee's test of cinematic meticulousness, Lorentz's film could not be deemed effective. And if effectiveness was the result of a film so perfect in its details that it could make even death obsolete, then the greatest crime imaginable was the kind of cinematic carelessness that uncomfortably characterized The Fight for Life.

The more recognizable artistry here is certainly Lorentz's: his cinematic 'symphonies' have remained legible, even if only at the margins of public memory, and his account of medicine's cultural values is enduring. Lorentz's medical characters are familiar, with the same seriousness of purpose, even at the cost of appearing emotionless; intense dedication to an explicitly technical medical craft; unrewarded, self-sacrificing behaviour; and an armament of medical tools that now widely characterize effective medical practitioners. ${ }^{67}$

The acts of reinstating DeLee as a subject in Lorentz's film and recovering his oeuvre from the archive offer enlightenment by way of vivid contrast. DeLee's films are not especially beautiful, but they are functional, multifaceted, cinematic 'symphonies' of another, tightly produced, highly detailed and therefore effective sort. Interjecting them into Lorentz's story does more than muddy the waters of Lorentz's supposed subject, DeLee himself. It also offers a glimpse of a critically dynamic moment in this conjoined history of medicine and film, in which the creative processes of each overlapped and commingled to reveal an unexpected iteration of medical effectiveness, DeLee's 'streamlined birth' just as it was passing out of fashion, thanks at least in part to Lorentz's quite different aesthetic choices.

66 DeLee to de Kruif, op. cit. (26).

67 This was certainly also a goal of Paul de Kruif's many works. About this film, he wrote that it was also 'the story of the power and glory of a new breed of man - the modern doctor'. Paul de Kruif, 'Speech to the WMCA and Inter-City', 6 March 1940, Box 30, Folder 1, Pare Lorentz Papers, Columbia University Archive. 